\title{
Climate change and the management of coastal resources
}

\author{
Luitzen Bijlsma* \\ National Institute for Coastal and Marine Management, Ministry of Transport, Public Works and Water Management, \\ Coastal Zone Management Centre, PO Box 20907, 2500 EX The Hague, The Netherlands
}

\begin{abstract}
In early 1996 the Intergovernmental Panel on Climate Change (IPCC) presented its Seconc Assessment Report 1995. In this paper some of the IPCC conclusions are discussed in the light of possible impacts on coastal resources and with respect to adaptation possibilities in coastal areas. It is concluded that present developments and trends in coastal areas are aggravating future impacts of climate change. It is also concluded that strengthening integrated coastal zone management efforts is the vehicle for improving the present day situation while at the same time accounting for future threats, which climate change is.
\end{abstract}

KEY WORDS: Climate change Sea level changes - Coastal zone management

\section{INTRODUCTION}

Within the context of the United Nations Framework Convention on Climate Change-signed by most countries in the world since the UNCED conference in Rio de Janeiro, Brazil - the ultimate objective is to stabilize greenhouse gas concentrations at a level where:

- ecosystems can adapt naturally

- food production is secured and

- economic development can proceed in a sustainable manner.

This ultimate objective, described in Article 2 of the Convention (UNEP/WMO 1992), makes clear that the global community can accept a certain level of climate change. The scale and intensity of the impacts on the one hand and the adaptation possibilities on the other will, however, ultimately trigger actions towards the stabilization and reduction of greenhouse gas emissions. The Intergovernmental Panel on Climate Change (IPCC) is a UN panel established to assess all relevant research in the field of climate change, its impacts and possible response strategies. In 1996 the

·E-mail: 1.bijlsma@rikz.minvenw.nl
IPCC published its Second Assessment Report (SAR) 1995 (IPCC 1996a, b). Some of the results and conclusions of the SAR 1995 for coastal systems and resources are highlighted in this paper.

\section{THE IPCC SECOND ASSESSMENT REPORT}

The most important indicator of climate change is global temperature. Global temperature has increased by half a degree Celsius in a century. This is a fact. The question is, Is this a result of man-induced climate change? Within the framework of the IPCC, temperature records like the one presented in the SAR and results of coupled atmosphere and ocean models have been compared. The results are given in Fig. 1. Coupled atmosphere-ocean-climate models can be considered as knowledge systems, comprising results of research on atmospheric, oceanic and terrestrial processes and their interactions. The inputs into the model are the reconstructed greenhouse gas emissions and the estimated increase in aerosols. The reasonable fit between observations and model results is one of the reasons the IPCC concluded in its SAR 1995 that man-induced global climate change is under way and that it is an ongoing process. 


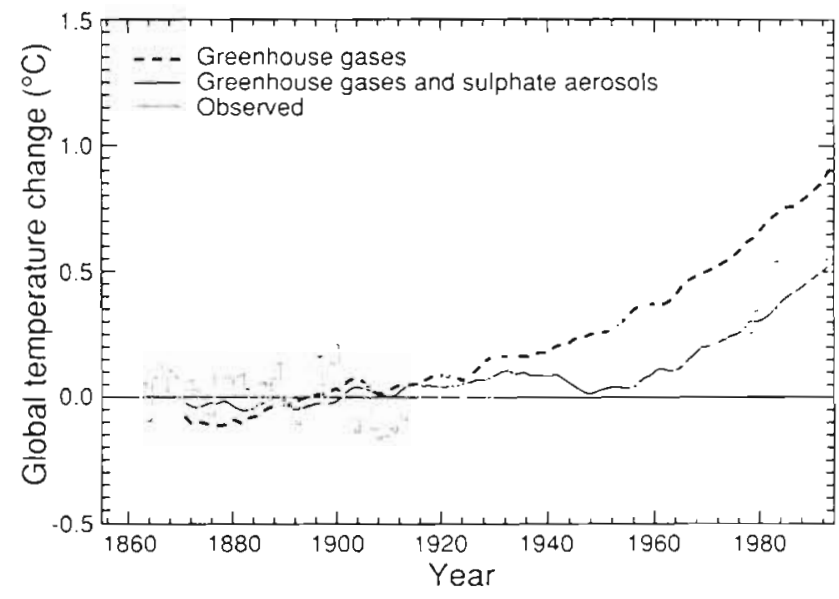

Fig. 1. Simulated global annual warming from 1860 to 1990 allowing for increases in greenhouse gases only (dashed curve) and greenhouse gases and sulphate aerosols (solid curve) compared with observed changes over the same period (grey line)

The coupled atmospheric ocean numerical models available at present provide information on projections of possible future emission and land use scenarios. With increasing greenhouse gases, the land tends to warm more than the oceans, as shown in one of the results of a global circulation model, the MRI model, as published in the SAR (Fig. 2). Such results, used as an example here, show a global warming for a 'business as usual' scenario for the year 2050. Note that on the global level the prediction has a certain robustness, although the regional or local reliability is low. Moreover, conclusions on effects of changes in climate variability such as storms, cyclones, floods, droughts, etc., all of importance for coastal areas, are not possible at this stage.

Still, it is important to consider that climate change will be experienced through its extremes first. This is true for all systems but especially in coastal areas. A coastal ecosystem or a coastal society can cope with a certain load of the extremes of a climate component, as indicated in Fig. 3. Take for example droughts, maximum wind speed or an extreme yearly flood event (UK Department of the Environment 1996). Climate change can lead to changes in the mean and the distribution of a climate component. Note that a small shift in the distribution can lead to a large shift in the frequency with which a critical value or a critical threshold is exceeded, as reflected in Fig. 3. Climate statistics can become unreliable through climate change, long before those changes can be distilled from recorded measurements.

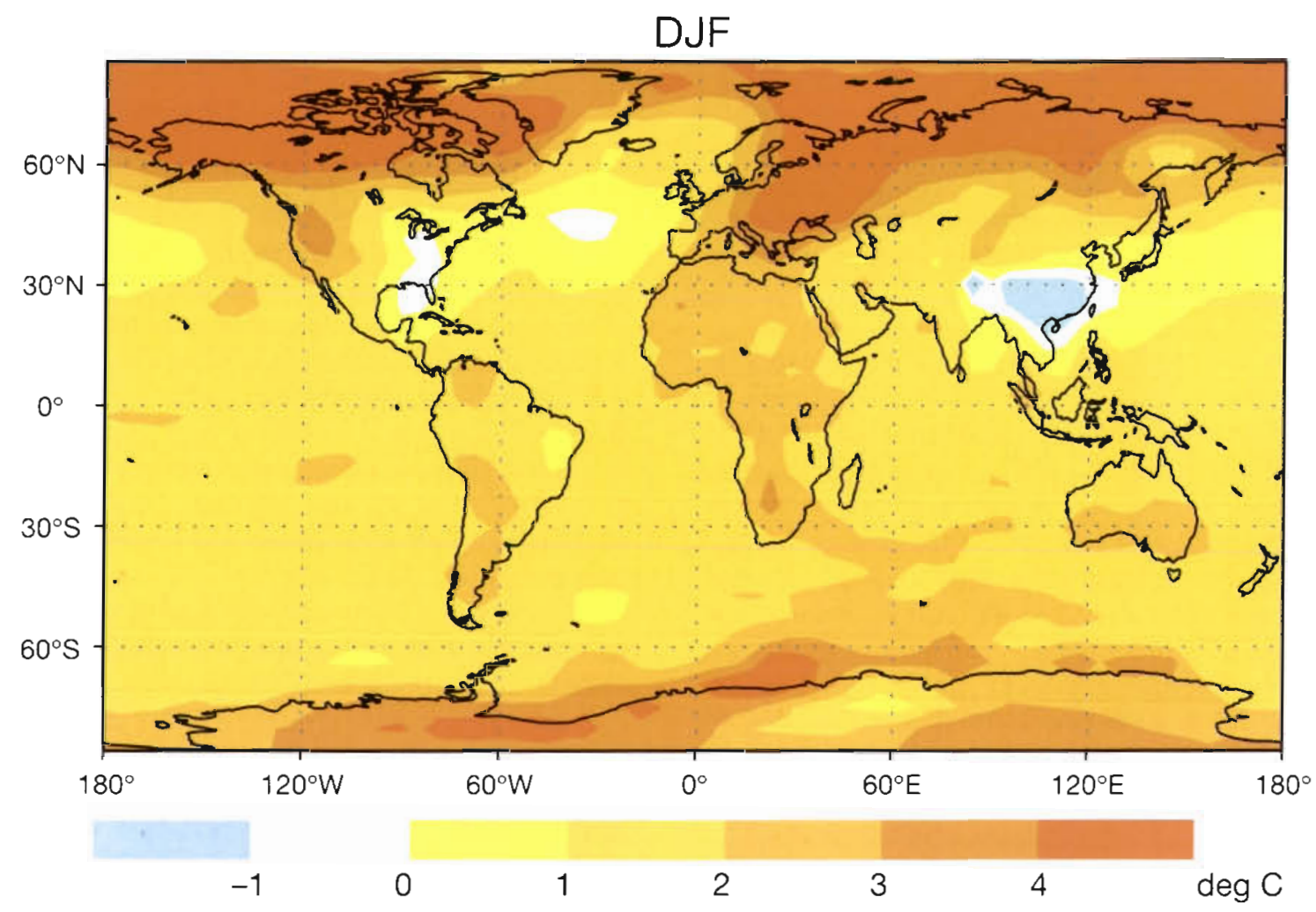

Fig. 2. Seasonal (Dec-Feb) change in surface temperature from 1880-1889 to 2040-2049, calculated by the MRl GCM 


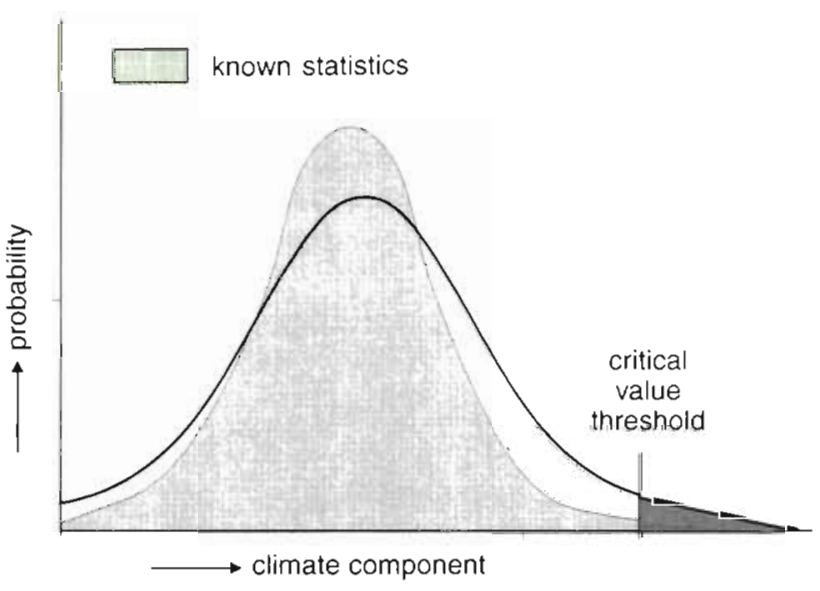

Fig. 3. Climate statistics and change. The shaded area reflects the known frequency of climate events or variables; the thick line reflects the hypothetical shift in the frequency distribution that can occur with climate change. The result is a significant relative increase in the frequency of extreme climatic variables (or events) exceeding the critical threshold

\section{SEA LEVEL AND CLIMATE CHANGES}

\subsection{Sea level changes}

Accelerated sea level rise is a predicted consequence of climate change. Sea level rise, as well as sea level fall, is experienced and recorded in many coastal countries. It is important to note that sea level change cannot be translated to a single global figure. Regional variations can be large and are caused by local subsidence, tectonic uplift or changes in ocean currents, such as the El Niño Southern Oscillation event. Some examples of tide gauge records, as given in Fig. 4, show how complicated the picture might be. Stockholm, for instance, shows a considerable sea level fall due to tectonic uplift as a result of glacial rebound since the last ice age. On the other hand, Bangkok shows a seriously accelerated sea level rise caused by, among other things, sediment compaction through increased groundwater extraction. Honolulu shows a stable picture that comes close to the global mean as recorded, whereas Nezugaseki in Japan shows a sudden shift in sea level as a result of an earthquake. The conclusion is that it is better to speak of relative sea level rise or sea level change.

An investigation of all reliable tide gauge records results in a picture of a global sea level rise of 10 to $25 \mathrm{~cm}$ over the past century. Trend analyses do not show an acceleration in sea level rise within this $100 \mathrm{yr}$ period, though this level of 10 to $25 \mathrm{~cm}$ per century is higher than over the past $1000 \mathrm{yr}$. The major contributors to the phenomenon of sea level change are listed in Table 1, as analyzed by the IPCC Working Group I

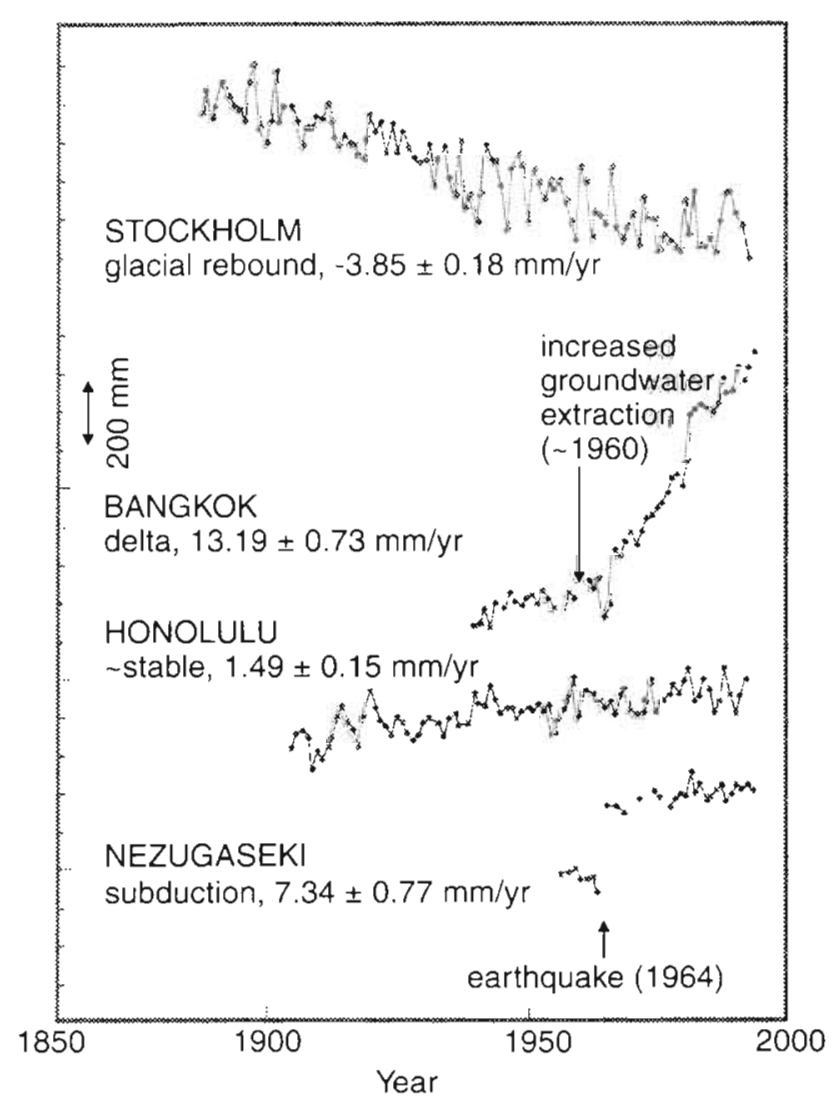

Fig. 4. Sea level changes at different locations around the world

(IPCC 1996a). The first factor is the thermal expansion of the ocean water. The recorded global atmospheric temperature rise over the past century of about $0.5^{\circ} \mathrm{C}$ resulted in a sea level rise of 2 to $7 \mathrm{~cm}$, with an average estimate of $4 \mathrm{~cm}$. The contribution from glaciers and small ice caps is well studied and values are relatively reliable. This contribution ranges from 3 to $4 \mathrm{~cm}$. More uncertain and very uncertain in this global ocean water balance estimate are, respectively the Greenland ice sheet and the Antarctic ice sheet. Here research cannot give reliable answers yet with regard to the question of whether those ice sheets are accumulating or losing ice mass. Finally, surface water storage in reservoirs, drainage, and groundwater exploitation are minor factors, but still with significant uncertainties.

This overall picture can lead to the conclusion that it is likely that the rise in sea level has been due largely to the concurrent increase in global temperature over the last 100 yr. Moreover, it might be concluded that an exact accounting for the past sea level rise is difficult, particularly in light of the large uncertainties associated with the mass balances of the large ice sheets. 
Table 1. Sources contributing to observed sea level rise over the last $100 \mathrm{yr}$. Values are in $\mathrm{cm}$

\begin{tabular}{lrcr|}
\hline Source & Low & Middle & High \\
\hline Thermal expansion & 2 & 4 & 7 \\
Glaciers/small ice caps & 2 & 3.5 & 5 \\
Greenland ice sheet & -4 & 0 & 4 \\
Antarctic ice sheet & -14 & 0 & 1.4 \\
Surface water and & -5 & 0.5 & 7 \\
$\quad$ groundwater storage & & & \\
Total & -19 & 8 & 37 \\
Observed & 10 & 18 & 25 \\
\hline
\end{tabular}

The IPCC, considering a Business As Usual emission scenario, concluded that there is a consensus that the sea level is projected to be about $50 \mathrm{~cm}$ higher than at present by the year 2100, as given in Fig. 5. Taking into account all uncertainties in emission scenarios as well as the process or model uncertainties, the range of sea level change is estimated to be between $10 \mathrm{~cm}$ and more than $1 \mathrm{~m}$ for the year 2100 . A couple of important notes can be added to this conclusion:

(1) First of all the response of the ocean and ice sheets shows a time lag. This implies that some of the coming sea level rise has already been determined. What is coming is partly predestined by emissions that have already occurred.

(2) Moreover, sea level rise will not stop in the year 2100 when, so we assume, the global community has stabilized $\mathrm{CO}_{2}$ concentrations. Even in that case the ocean will continue to rise for a century or more and the potential change is much more than $1 \mathrm{~m}$.

(3) Finally, there is also evidence that the rise in sea level will not be uniform all over the globe, but will differ significantly from region to region due to differences in the rise of ocean temperature and to possible changes in ocean currents caused by climate change. For example, where the warming in the southern hemisphere seems to be less than the global average, this might lead to lower sea level projections than the global average.

\subsection{Other climate changes}

Sea level changes as a result of global warming is an important phenomenon for coastal areas. Changes in other climate components can, however, also be of utmost importance. In particular, climate variabil- ity, e.g. in precipitation and changes in the wind speed and wind direction, can be as important with respect to damage as the sea level changes discussed above. To give an example, for The Netherlands a change of $10 \%$ in storm frequency has an impact on risk levels comparable to a $1 \mathrm{~m}$ rise in sea level (Peerbolte et al. 1991). The IPCC SAR concludes that extreme events of great importance for coastal systems, such as tides, waves, storm surges, storms and cyclones, could be affected by regional climate changes. It also concludes that, in the present state of knowledge, a reliable prediction is not possible. For impact studies it is therefore recommended that a broad bandwidth be assumed in considering the impact of changes in climate variability.

\section{IMPACTS ON COASTAL ZONES AND SMALL ISLANDS}

\subsection{Trends and developments}

The possible impacts of climate and sea level changes have been intensively studied by the IPCC since the IPCC First Assessment Report 1990. The IPCC Working Group on 'Coastal Zones and Small Islands' concluded that the impacts of climate change cannot be studied in isolation (IPCC 1996b). Impacts have to be considered in the real world and in the context of the coastal trends and developments of today.

Coastal zones and small islands are characterized by highly diverse ecosystems and are important as a source of food and as habitat for many species. They also support a variety of economic activities which in many places have led to a high rate of population 
growth and economic development. The response of coastal ecosystems to climate change and sea level rise is strongly and/or will be strongly influenced by continuing developments-developments that in many cases lead to overexploitation of resources, pollution, sediment starvation and fragmentation of ecosystems through urbanization and development of infrastructure (World Coast Conference 1993). These developments will, on an increasing scale:

- lead to a decrease in the resilience of coastal systems in coping with natural climate variability;

- adversely affect the natural capability of these systems to adapt to changes in climate;

- lead to increased hazard potential for coastal populations, infrastructure and investments.

In many cases, therefore, the assessment of impacts of climate change in coastal areas involves the estimation of the additional risk that is posed by climate change to systems that already are under significant stress.

\subsection{Coastal ecosystem stress}

The reduced resilience of coastal natural systems on a global scale has been investigated by a number of researchers. As a recent example, the World Resources Institute (WRI 1995) used a method that introduced a robust and, therefore, simplified global overview of the present stress to coastal ecosystems. The main factors that are widely identified as major threats to coastal ecosystems are: habitat loss, pollution, overfishing and species introduction. These direct stress factors can be linked to what are called indirect stress factors or human actions that contribute to the given type of stress. For instance, coastal development is one indirect stressor leading to habitat loss. Most of the indirect stress factors are represented by indicators as cities, major ports, population density, road density and pipeline density. These indicators cover a series of human actions and interventions in coastal ecosystems (Table 2). Not everything is included in this approach. For instance, changes in catchment areas have not been taken into account, nor has increased siltation due to deforestation and agricultural practices, a major factor behind the degradation of coral reefs and other habitats. The indicators presented here can be connected to the stress factors and expressed in quantitative terms using global databases.

\subsection{Coastlines at risk}

In classifying the risk indicators into high, medium and low potential stress, WRI derived a global and regional picture (Fig, 6). The results show that about $34 \%$ of the world's coast is confronting a high potential threat, $17 \%$ a medium and $49 \%$ a low potential threat.

The status of marine protected areas can also be considered in this context, by using a recently developed map of marine protected areas. This map contains the coordinates of over 1000 marine protected areas. The majority are located in zones with high threat from development. This underlines the importance of these marine protected areas as the front line in establishing action towards sustainable development.

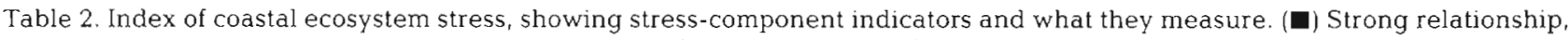
(A) moderate relationship, (1) weak relationship

\begin{tabular}{|c|c|c|c|c|c|c|}
\hline \multirow{2}{*}{ Direct stressor } & \multirow{2}{*}{ Indirect stressor } & \multicolumn{5}{|c|}{ _ Indicator } \\
\hline & & Cities & $\begin{array}{l}\text { Major } \\
\text { ports }\end{array}$ & $\begin{array}{l}\text { Population } \\
\text { density }\end{array}$ & $\begin{array}{c}\text { Road } \\
\text { density (access) }\end{array}$ & $\begin{array}{l}\text { Pipeline } \\
\text { density }\end{array}$ \\
\hline Habitat loss & $\begin{array}{l}\text { Coastal development } \\
\text { Degradation through harvesting } \\
\text { Aquaculture } \\
\text { Change in freshwater flows }\end{array}$ & $\dot{\Delta}$ & $\dot{\Delta}$ & $\begin{array}{l}\Delta \\
\Delta\end{array}$ & $\hat{\Delta}$ & \\
\hline Pollution & $\begin{array}{l}\text { Untreated sewage } \\
\text { Industrial pollution } \\
\text { Deforestation and agricultural, nonpoint } \\
\text { Siltation } \\
\text { Oil spills } \\
\text { Atmospheric emission }\end{array}$ & 口 & $\hat{\bullet}$ & - & - & $\Delta$ \\
\hline $\begin{array}{l}\text { Overfishing } \\
\text { Species introductions } \\
\text { (from ballast water) }\end{array}$ & Overfishing & 0 & $\mathbf{A}$ & 0 & - & \\
\hline
\end{tabular}




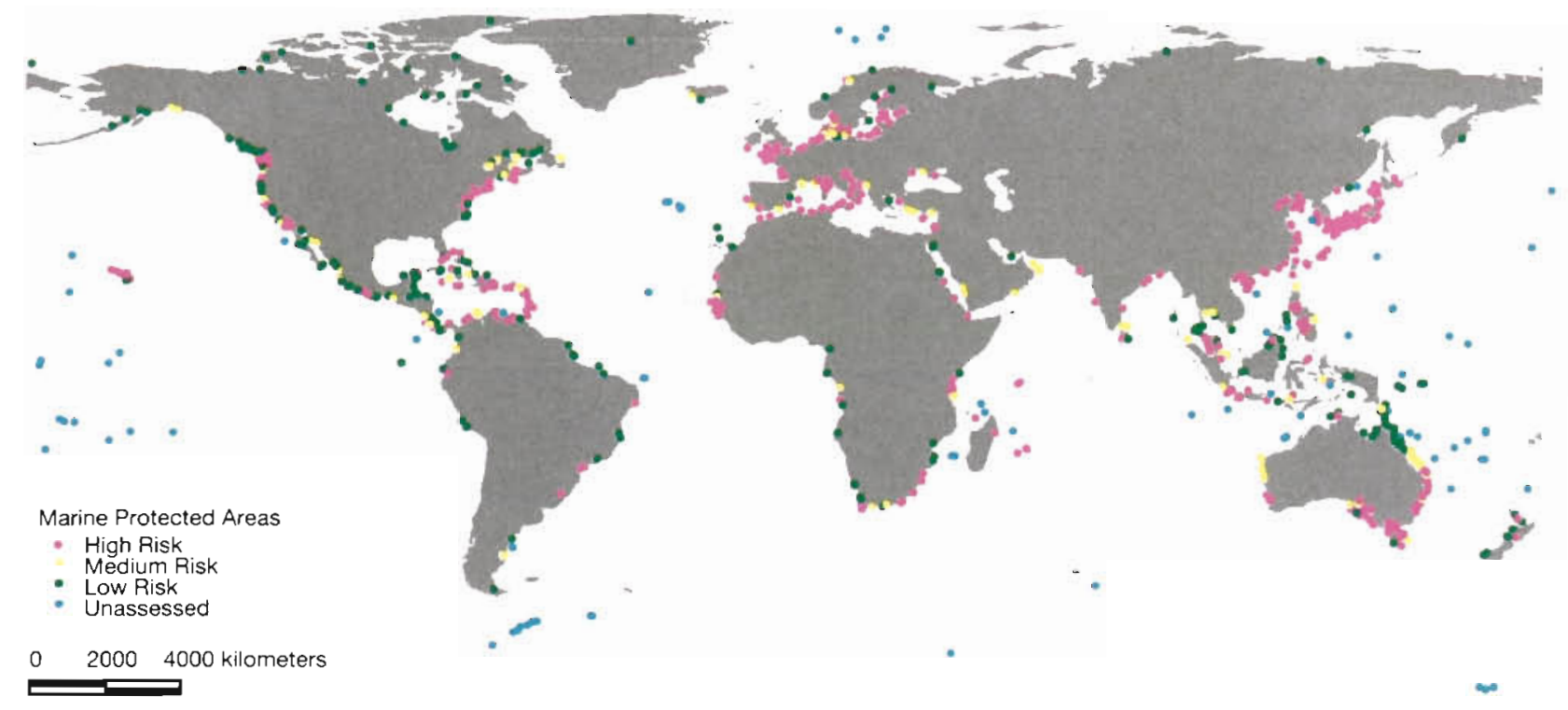

Fig. 6. Index of potential development-related threat on a global scale. From World Resources Institute (1995)

\subsection{The Netherlands}

Let's take a sample case from this global picture: The Netherlands. An assessment of the marine and coastal ecosystem stress is expressed by a diagram called the AMOEBA. AMOEBA is an assessment method developed for the Dutch marine waters and coastal zones (Ministry of Agriculture, Nature Management and Fisheries/Ministry of Transport, Public Works and Water Management 1995). AMOEBA is an acronym for 'A general Method Of Ecological and Biological Assessment'. On the circle a selection of key species of the marine environment is represented (Fig. 7). The extent of the shaded area from the centre of the circle to the outside gives an indication of the number of key species. The numbers for the year 1930 are considered to be a reference and are therefore represented as $100 \%$, or the full circle. The year 1930 was considered to be a relatively undisturbed, pre-industrial situation, and serves as a model for a sustainable situation. The present situation, compared to the reference 1930 situation, is reflected in Fig. 7. To give an example, the reference for seals and sea grasses in The Netherlands is 9000 seals and 16000 ha of sea grasses in 1930. The present figures are 450 seals and 300 ha of sea grasses. The overall picture shows that:

- algal biomass has grown rampantly;

- sea mammals have almost disappeared;

- shore and water-plants, kelp and many fish species have decreased dramatically;

- oystercatchers and eider ducks seem to have profited from the changes; and finally,
- there is a general shift from long living to short living species.

Certainly The Netherlands case study shows that the indicated stress for the coastal ecosystem seems to be correct.

\subsection{Climate change and natural coastal systems}

As was indicated earlier, the impacts of climate change should be considered within the context of the present coastal development and stress to ecosystems. The IPCC has assessed all recent studies on the sensitivity of the main biogeophysical coastal systems (IPCC 1996b). The assessment leads to the main conclusion that in general the coast is not a passive system but responds to sea level and other climate changes. Specifically, the following IPCC conclusions were:

(1) In the past, estuaries and coastal wetlands could often cope with sea level rise, although usually by migrating landward.

An increasing conflict can be observed in many cases within the framework of physical planning or land use planning. The question is: do we plan for this coastal system response by implementing setback possibilities?

(2) Survival of salt marshes and mangroves is likely where the rate of sedimentation will almost be equal to the local rate of sea level rise.

An increasing conflict can be observed in many cases within the framework of resource use management as mining, shoreline modifications and 


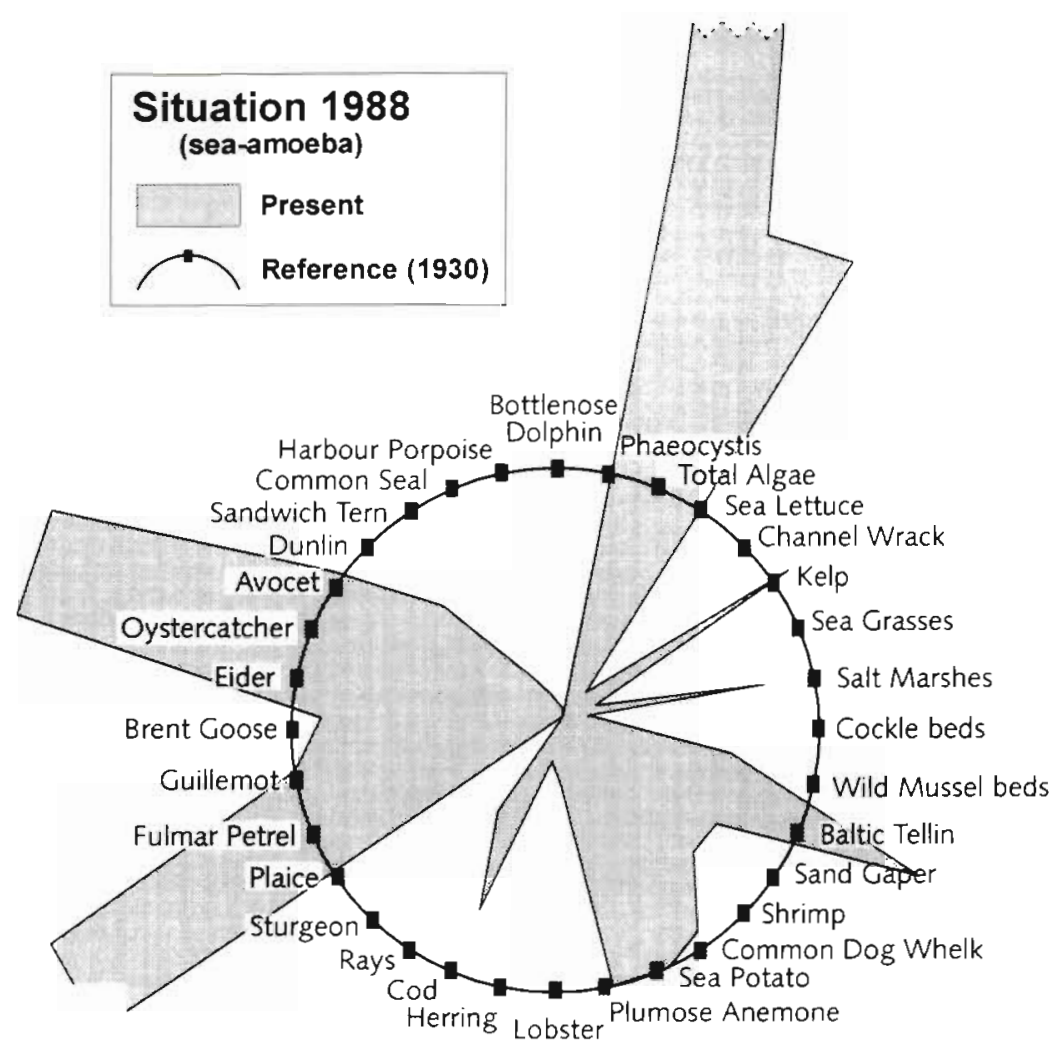

Fig. 7. Status and trends in a coastal and marine ecosystem: The Netherlands case. The diagram indicates species abundances as of 1988 relative to those in 1930

modifications in the catchment areas. The question is: do we consider sediment balances on different time and space scales in coastal resource use management practices?

(3) Generally, coral reefs have the capacity to keep pace with projected sea level rise, but may suffer from increases in sea water temperature. If the temperature elevation departs from the seasonal maximum substantially (a couple of ${ }^{\circ} \mathrm{C}$ ) for an extended period ( $1 \mathrm{mo}$ ) coral mortality or bleaching can be expected.

Corals under stress of human use like dynamiting, pollution, anchoring or siltation will be more vulnerable to additional climate change stresses. The question is: do we consider integration of developing policies for the exploitation of resources, pollution prevention schemes, development and tourism?

\subsection{Climate change and increased hazard potential}

Considering the socio-economic development in coastal zones and small islands, the IPCC concluded that climate change would have negative impacts on most sectors, including tourism, fresh water supply, fisheries, agriculture, human settlements, financial services and human health. The number of people that risk flooding can double or triple in the case of the projected sea level rise, not to mention the potential threat of increased frequency or intensity of storms. Protection measures will be costly to very costly in certain settings like low-lying small island states and deltaic areas. Adaptation to climate change in terms of physical protection will involve important trade-offs, taking account of environmental, economic, social and cultural values.

\section{CLIMATE CHANGE AS A DRIVING FORCE FOR IMPROVING MANAGE- MENT}

\subsection{Interactions and integration}

Integrated coastal zone management (integrated because of the many interactions between resource users and the coastal systems) has been identified and highlighted by the IPCC and also by the United Nations Framework Convention on Climate Change as the most important vehicle for adapting to climate change while at the same time improving the present situation in coastal areas. Other calls to coastal countries have come from the Convention on Biological Diversity and the Global Action Programme on Land Based Sources of Marine Pollution, both anchored within Agenda 21 of UNCED. Climate change adaptation options should be embedded within a coastal management and planning effort which includes all systems and sectors involved. Though the emphasis of planning and management efforts are focused on present day-to-day needs, the following options or a combination of options can be incorporated into planning and management processes for coastal areas. Many such options have long lead times, some options might be costly, and others will be difficult to enforce (Table 3).

Retreat options will emphasize abandonment of land and structures in highly vulnerable areas and the resettlement of inhabitants. Management action can comprise the prevention of development or the withdrawal of governmental subsidies.

Accommodate options will emphasize the conservation and resilience of ecosystems, to be harmonized with socio-economic developments. Adaptive manage- 
Table 3. Response strategies of integrated coastal zone management to sea level rise

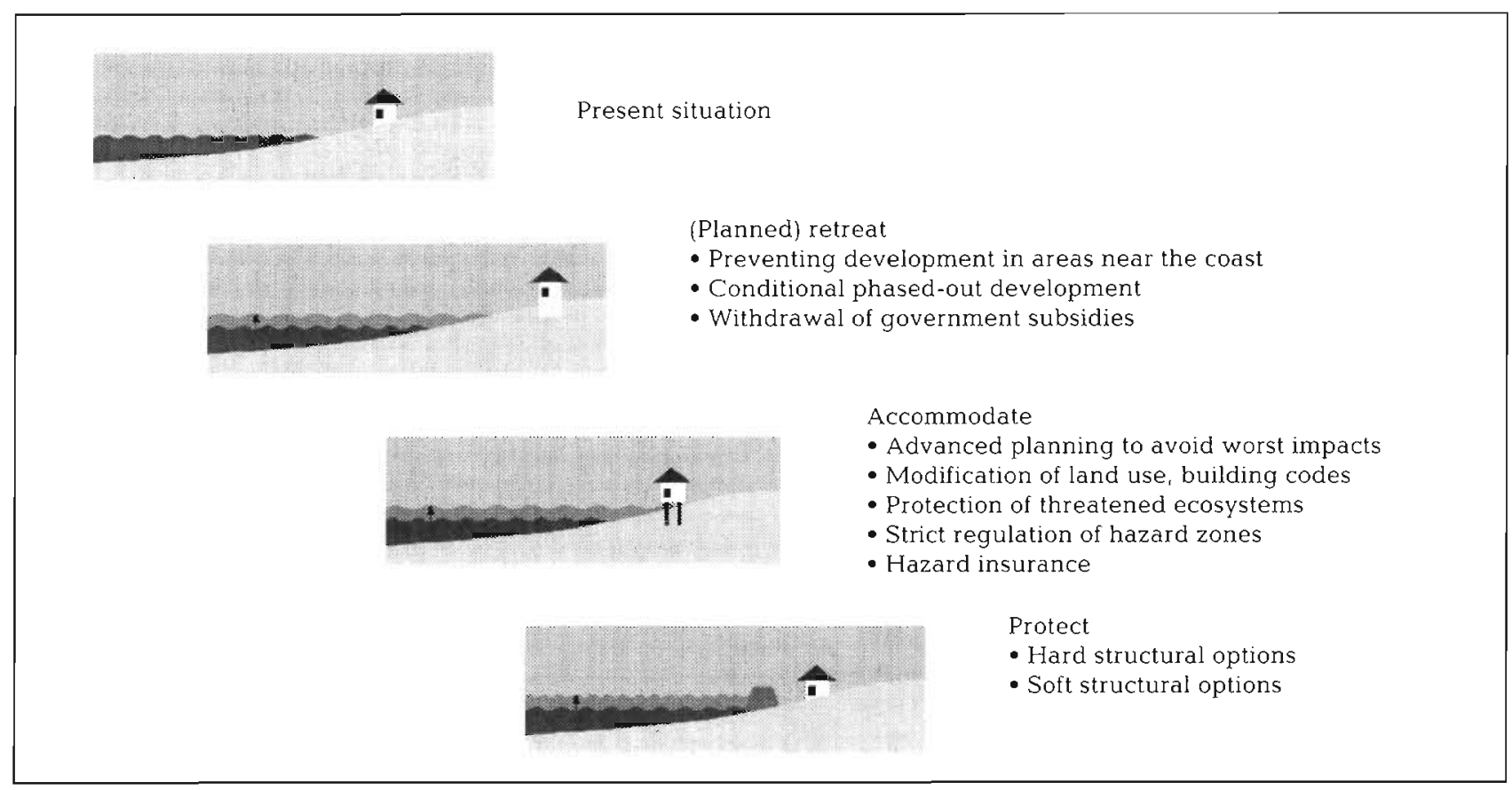

\begin{tabular}{|c|c|c|c|c|}
\hline \multicolumn{5}{|c|}{ rostal Zour cromenaure } \\
\hline & Arrangements & & Objectives & Ethics \\
\hline $\begin{array}{c}\text { Organizationat } \\
\text { structure }\end{array}$ & $\begin{array}{c}\text { Legal } \\
\text { framework }\end{array}$ & $\begin{array}{l}\text { Tradition and } \\
\text { social norms }\end{array}$ & $\begin{array}{c}\text { Safety } \\
\text { Resources } \\
\text { Development }\end{array}$ & $\begin{array}{l}\text { Integration } \\
\text { Harmonization } \\
\text { Participation }\end{array}$ \\
\hline
\end{tabular}

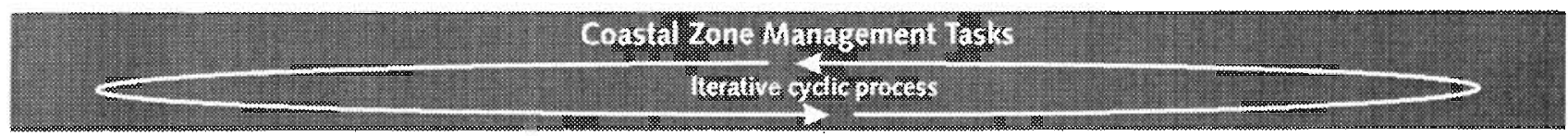

\begin{tabular}{|c|c|c|c|c|c|c|c|}
\hline $\begin{array}{l}\text { Problem } \\
\text { Recognition }\end{array}$ & Planning & & & Implementation & & & Evaluation \\
\hline \multirow[t]{2}{*}{$\begin{array}{l}\text { Research } \\
\text { Assessment }\end{array}$} & Data Collection & Policy Development & Decision Making & Plan Execution & $\begin{array}{l}\text { Operation and } \\
\text { Maintenance }\end{array}$ & Monitoring & $\begin{array}{l}\text { Assessment } \\
\text { and Outlook }\end{array}$ \\
\hline & \multicolumn{6}{|c|}{ Corstal Zone Manazenent lnstruments and Capacities } & \\
\hline $\begin{array}{l}\text { Education } \\
\text { and awareness } \\
\text { programs } \\
\text { research } \\
\text { public } \\
\text { participation }\end{array}$ & $\begin{array}{l}\text { Ecological } \\
\text { databases } \\
\text { demographic and } \\
\text { economic statistics } \\
\text { natural resources } \\
\text { accounting }\end{array}$ & $\begin{array}{l}\text { Systems analysıs } \\
\text { - natural system } \\
\text { - socio-economic system } \\
\text { - user functions } \\
\text { - management system } \\
\text { muitı disciplinary } \\
\text { cooperation }\end{array}$ & $\begin{array}{l}\text { Decision support } \\
\text { systems } \\
\text { costbeneft, } \\
\text { multi-criteria and } \\
\text { eco-eco valuation } \\
\text { open planning } \\
\text { procedures with } \\
\text { stakeholders and } \\
\text { users }\end{array}$ & $\begin{array}{l}\text { Regulatory and } \\
\text { non-regulatory } \\
\text { measures } \\
\text { funding } \\
\text { mechanisms } \\
\text { guidelines }\end{array}$ & $\begin{array}{l}\text { Operational } \\
\text { procedures } \\
\text { - entorcement } \\
\text { - maintenance } \\
\text { - hazard } \\
\text { management }\end{array}$ & $\begin{array}{l}\text { Objective oriented } \\
\text { monitoring scheme } \\
\text { research and } \\
\text { analysis facilties } \\
\text { remote sensıng and } \\
\text { GIS databases }\end{array}$ & $\begin{array}{l}\text { Object oriented } \\
\text { evaluation } \\
\text { open procedure with } \\
\text { stakeholders and } \\
\text { users } \\
\text { public hearing }\end{array}$ \\
\hline
\end{tabular}

Fig. 8. The elements of coastal zone management 
ment responses can include modification of land use, the protection of ecosystems, strict set-back regulations to prevent developments in hazardous zones or insurance policies.

Protect options will emphasize the defense of highly populated and developed areas, their natural resources and economic activities. Hard structural measures, such as dikes, groins, barriers, sea walls and revetments, may sometimes be necessary but have their trade-offs. Soft structural options, such as beach nourishment, dune restoration and afforestation, are more flexible.

\subsection{The elements of coastal zone management}

In considering the strengthening of management practices, the basic elements of integrated coastal zone management should be identified. These elements can be grouped at 3 levels: the level of governance; the level of management tasks; and the level of the tools, instruments and capacities to support the management tasks (Fig. 8).

On the level of coastal governance, institutional and legal arrangements should be considered. There is no universal approach, but the organization will be based on tradition and social norms of a nation. Also, on the political level, objectives have to be formulated. In fact, there are 3 typical governmental tasks that cannot be organized by the private sector: public safety; access to or division of resources among the users; and, finally, stimulation of desired developments. Additionally, an ethical approach should be anchored on the level of governance through integration or harmonization (horizontal and vertical) and by stimulating participation. If the government in different sectors and at different levels does not get its act together, there is little hope that people will understand the management program. Governmental policy is basically about influencing people's behaviour.

On the level of coastal zone management tasks, a cyclical approach typically exists, from problem recognition to planning, implementation and evaluation. Here the coastal zone manager has to consider: programs for research, data collection and policy development; decision-making processes for plan execution, operation and maintenance; and programs for monitoring of the developments in relation to the set objectives and criteria. In conclusion, or as a beginning of a new cycle, a programme for evaluation and outlook can be distinguished.

Finally, on the level of coastal zone management instruments and capacities, a long checklist can be developed. Some efforts also have been undertaken to define guidelines for coastal zone management. In general, the development of a program is site-specific and setting-specific. Problem recognition can be supported by education and awareness programs coupled with research programs and public participation. A multidisciplinary approach in system analyses and decision-making processes can avoid make-do solutions.

The basis of a plan of execution is the funding of the management tasks. An overview of funding sources and mechanisms shows that internal funding sources of the country or the island concerned are the most important, much more so than external financial sources such as grants and multilateral loans. Internal financial sources can include user charges to ensure that those who benefit contribute to the costs of the service. It may involve charging the polluter systems. Such money can be reinvested in subsidies to stimulate sanitation programs or be invested in technology to prevent pollution. The above-mentioned charges, in combination with local or national taxes, are the basis for every program. The private sector can be involved in some cases through borrowing, the set-up of a revolving fund, or private sector participation.

\section{CONCLUSION}

Climate change is not an impending catastrophe. It is a sneaky, ongoing, long-term threat. Its impacts will be strongly determined by the quality of our decision-making for the exploitation of coastal areas. The decisionmaking done so far can, in general, be qualified as very poor and unsustainable. Therefore, adaptation is, in many cases, the improvement of coastal management through capacity building. Herein lies the challenge.

\section{LITERATURE CITED}

IPCC (Intergovernmental Panel on Climate Change) (1996a) Second Assessment Report; Climate Change 1995; the science of climate change. Cambridge University Press, Cambridge

IPCC (Intergovernmental Panel on Climate Change) (1996b) Second Assessment Report; Climate Change 1995; impacts, adaptations and mitigation of climate change. Cambridge University Press, Cambridge

Ministry of Agriculture, Nature Management and Fisheries/Ministry of Transport, Public Works and Water Management (1995) The Netherlands coastal and marine biodiversity. (Report.) The Hague

Peerbolte EB, de Ronde JG, de Vrees LPM, Mann M, Baarse $G$ (1991) Impacts of sea level rise on society: a case study for The Netherlands. Delft Hydraulics and Ministry of Transport, Public Works and Water Management, Delft

UK Department of the Environment (1996) Review of the potential effects of climate change in the United Kingdom. United Kingdom Climate Change Impacts Review Group. Her Majesty's Stationery Office, London, p 13-14

UNEP/WMO (United Nations Environment Programme/ 
World Meteorological Organization) (1992) United Nations Framework Convention on Climate Change. Climate Change Secretariat, Geneva

World Coast Conference (1993) Preparing to meet the coastal challenges of the 21st century: conference report. Ministry of Transport, Public Works and Water Management,
National Institute for Coastal and Marine Management (RIKZ), The Hague

WRI (World Resources Institute) (1995) Coastlines at risk: an index of potential development-related threats to coastal ecosystems. World Resources Institute Indicator Brief, Washington, DC 